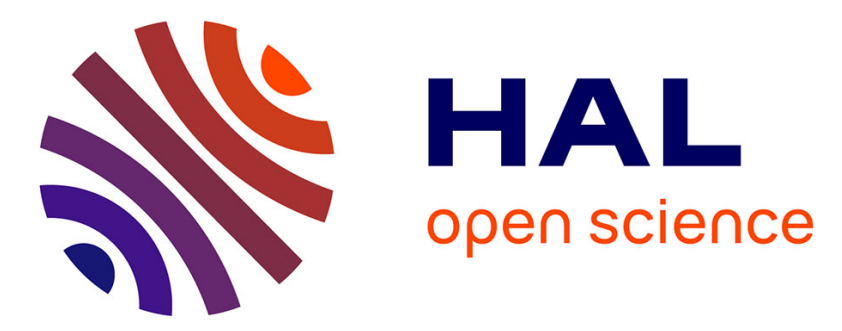

\title{
A role for peroxisome proliferator-activated receptor gamma in resveratrol-induced colon cancer cell apoptosis.
}

Virginie Aires, Bertrand Brassart, Annie Carlier, Alessandra Scagliarini, Stéphane Mandard, Emeric Limagne, Eric Solary, Laurent Martiny, Michel Tarpin, Dominique Delmas

\section{To cite this version:}

Virginie Aires, Bertrand Brassart, Annie Carlier, Alessandra Scagliarini, Stéphane Mandard, et al.. A role for peroxisome proliferator-activated receptor gamma in resveratrol-induced colon cancer cell apoptosis.. Molecular Nutrition and Food Research, 2014, 58 (9), pp.1785-94. 10.1002/mnfr.201300962 . inserm-01016743

\section{HAL Id: inserm-01016743 https://www.hal.inserm.fr/inserm-01016743}

Submitted on 1 Jul 2014

HAL is a multi-disciplinary open access archive for the deposit and dissemination of scientific research documents, whether they are published or not. The documents may come from teaching and research institutions in France or abroad, or from public or private research centers.
L'archive ouverte pluridisciplinaire HAL, est destinée au dépôt et à la diffusion de documents scientifiques de niveau recherche, publiés ou non, émanant des établissements d'enseignement et de recherche français ou étrangers, des laboratoires publics ou privés. 


\section{A role for Peroxisome Proliferator-Activated Receptor gamma in}

\section{Resveratrol induced colon cancer cell apoptosis.}

Virginie Aires, ${ }^{1,2}$ Bertrand Brassart, ${ }^{3}$ Annie Carlier, ${ }^{3}$ Alessandra Scagliarini, ${ }^{1,2}$ Stéphane Mandard, ${ }^{1,4}$ Emeric Limagne, ${ }^{1,2}$ Eric Solary, ${ }^{5}$ Laurent Martiny, ${ }^{3}$ Michel Tarpin, ${ }^{3}$ and Dominique Delmas ${ }^{1,2}$

1 - Université de Bourgogne, Dijon, F-21000, France; 2 - Centre de Recherche INSERM U866 - Equipe Chimiothérapie, Métabolisme Lipidique et Réponse Immunitaire Antitumorale, Dijon, F-21000, France ; 3 - Université de Reims Champagne Ardenne, Faculté des Sciences Exactes et Naturelles, FRE CNRS 3481 MEDyC, IFR 53, F-51687 Reims, France ; 4 - Centre de Recherche INSERM U866 - Equipe Protéines de transfert des lipides et métabolisme des lipoprotéines, 21079 Dijon, France ; 5 -Inserm UMR 1009, Institut Gustave Roussy, 114 rue Edouard Vaillant, 94805, Villejuif cedex, France

To whom all correspondence should be addressed:

Dr. Dominique Delmas

Centre de Recherche Inserm U866 "Lipids, Nutrition, Cancer"

Faculty of Medicine

7, Bd Jeanne d'Arc,

21000 Dijon, France

Phone: +33380393226

Fax: + 33380393434

Email: ddelmas@u-bourgogne.fr

Key words: resveratrol, PPAR, polyphenols, colon cancer 


\begin{abstract}
Scope

Resveratrol may function as a chemopreventive agent.. A recent clinical study demonstrates a reduction in tumor cell proliferation in colorectal patients receiving repeated oral ingestion of resveratrol. However, gaps remain in our knowledge of the molecular mechanisms by which resveratrol exerts its chemopreventive effect. We have previously demonstrated that resveratrol induces apoptosis in colon cancer cells and that resveratrol can sensitize chemoresistant colon cancer cells to various drugs. Based on its ability to activate PPAR $\gamma$ (Peroxisome Proliferator-Activated Receptor gamma) in colon cancer cells, we sought to determine the implication of this nuclear transcription factor in resveratrol-induced apoptosis.

\section{Methods and results}

Transient transfection of cancer cells with a dominant-negative PPAR $\gamma$ mutant or treatment with a PPAR $\gamma$ antagonist (GW9662) reversed the inhibitory effect of resveratrol. Moreover, GW9662 prevented disruption of the cell cycle induced by resveratrol and consequently abrogated resveratrol-induced apoptosis. Tumor cell death was potentiated by combining resveratrol with rosiglitazone, a PPAR $\gamma$ agonist, supporting the notion that combining a resveratrol/PPAR $\gamma$ agonist could be a promising pharmacological approach for treatment of colorectal cancer.

\title{
Conclusion
}

Altogether, the results show that PPAR $\gamma$ could mediate a part of the chemopreventive activity of RSV in colon cancer and the combination of RSV with PPAR $\gamma$ modulators. 


\section{Introduction}

Generally speaking, the prevention of tumor development is more relevant than treating established disease. Avoidance of risk behaviors remains the most efficient approach for cancer prevention, but the development of active strategies such as the consumption of chemopreventive agents is another area of intense investigation. Among these compounds, natural products such as dietary polyphenols have demonstrated promising properties through epidemiological and experimental studies [1-3]. Resveratrol (trans-3,4',5-trihydroxystilbene, RSV), a wine grape microcomponent, appears to be one of the most efficient polyphenols [4] because it may prevent the occurrence of vascular diseases, neurodegenerative processes and some malignant tumors (see for review [5, 6]). These preventive actions of resveratrol have been extensively studied in colon carcinoma models, both in vitro $[5,7,8]$ and in vivo $[6,7$, 9]. In particular, ingestion of RSV was observed to reduce the number of preneoplastic lesions as well as the incidence and multiplicity of tumors in animal models [9, 10]. Most importantly, clinical trials have been launched in cancer patients (registered in www.ClinicalTrials.gov). Several phase I/II clinical trials are currently underway for resveratrol, including National Cancer Institute-sponsored studies at the University of Michigan in the US and the University of Leicester in the UK. In this last study, Brown's team has shown in a phase I/II clinical trial that the levels of RSV and RSV metabolites (sulfate and glucuronides) measured in human colorectal tissue after repeated oral ingestion of $1 \mathrm{~g}$ for 8 days were correlated with a $5 \%$ reduction in tumor cell proliferation, confirming the potential anticarcinogenic properties of RSV [11].

At the molecular and cellular level, we and others have previously demonstrated that the ability of RSV to prevent the occurrence of colon carcinomas is related to the inhibition of the tumor cell cycle $[12,13]$ and to the induction of cell death in colon cancer cells [14]. To trigger these effects, RSV accumulates in plasma membrane lipid rafts, enters the cancer cell 
by endocytosis and activates the mitogen-activated protein kinase (MAPK) pathway [15]. Thus, MAPK integrin $\alpha_{v} \beta_{3}$ complexes are activated, which subsequently play important roles in apoptosis induced by RSV [15]. Nevertheless, disruption of lipid rafts and inhibition of the integrin $\alpha_{\mathrm{v}} \beta_{3}$ complexes did not completely abolish the effect of RSV, suggesting that there are other actors playing a role in the molecular effect [15]. Among the different potential candidates, the nuclear transcription factor PPAR $\gamma$ (Peroxisome Proliferator-Activated Receptor gamma) could be another essential target for mediating some of RSV's effects. In support of this hypothesis, a previous report established that the activation of the spermidine/spermine $\mathrm{N}(1)$-acetyltransferase (SSAT), which is a rate-limiting enzyme in polyamine catabolism, is induced by RSV through a PPAR $\gamma$-dependent mechanism [8]. This RSV-dependent PPAR $\gamma$ activation seems to be mediated, at least partly, by the activation of the ligand-binding domain (LBD/AF2) of the nuclear receptor [8]. Yet, the role of PPAR $\gamma$ in RSV-induced cell death and in its chemopreventive properties remains ill-defined and deserves further investigation.

In the present study, we addressed a new role of PPAR $\gamma$ in RSV-induced apoptosis and in RSV-induced proliferation inhibition in colon carcinoma cells. Using a specific PPAR $\gamma$ antagonist and a dominant negative mutant form of PPAR $\gamma$, it was shown that this receptor is required for 1) RSV-induced accumulation of colorectal tumor cells in the S phase of the cell cycle and 2) RSV-induced inhibition of colon cancer cell viability. Combined, these events contribute to the induction of colon cancer cell apoptosis. Notably, the combination of RSV with a PPAR $\gamma$ agonist, namely rosiglitazone, increases the ability of RSV to induce colon cancer cell death. 


\section{Materials and methods}

\subsection{Cell lines, expression vectors and transient transfections}

Human colon carcinoma cell lines SW480, HCT116, Caco2 and SW620 were obtained from the American Tissue Culture Collection (ATCC, Rockville, MD, USA) and were maintained in RPMI 1640 medium, (Biowhittaker Co., Fontenay-sous-Bois, France) supplemented with $10 \%$ fetal calf serum and $2 \mathrm{mM} \mathrm{L-glutamine} \mathrm{(Biowhittaker).} \mathrm{The} \mathrm{vectors} \mathrm{used} \mathrm{for}$ transfections include pcDNA3 (Invitrogen) as an empty vector for control transfection, and plasmid pcDNA3-PPAR $\gamma$ L468A/E471A, a dominant-negative double mutant (a kind gift from Prof. V.K. Chatterjee, Department of Medicine, University of Cambridge, Addenbrooke's, Cambridge, UK) [16]. Exponentially growing cells were incubated with a mixture of $9 \mu \mathrm{L}$ Fugene (Roche Diagnostics Corporation, Indianapolis, IN, USA) with $1 \mu \mathrm{g}$ of the above-indicated plasmid together with $1 \mu \mathrm{g}$ of an EGFP-encoding plasmid (pEGFP-C1, Clontech, Palo Alto, CA, USA). Transfected cells were treated $24 \mathrm{~h}$ later for indicated times before measuring the number of EGFP-positive, survival and apoptotic cells.

\subsection{Drugs, chemical reagents and antibodies}

Trans-resveratrol (RSV), propidium iodide and Hoechst 33342 were obtained from SigmaAldrich (St-Quentin-Fallavier, France). We used rabbit polyclonal antibodies (Abs) against human caspase-3 active form from Cell Signalling Technologies (Beverly, MA, USA) and mouse monoclonal $\mathrm{Ab}$ against $\beta$-actin from Sigma-Aldrich (St-Quentin-Fallavier, France). GW9662 and rosiglitazone were purchased from Bertin Pharma (Montigny-le-Bretonneux, France). The PPAR $\alpha$ antagonist, GW6471, and the PPAR $\beta / \delta$ antagonist, GSK0660, were purchased from Sigma-Aldrich. 


\subsection{Cell viability measurements}

Colon carcinoma cells were seeded $24 \mathrm{~h}$ before treatment into 24 well plates in complete growth medium. The next day, cells were challenged for 24 and $48 \mathrm{~h}$ with RSV at $30 \mu \mathrm{M}$, a concentration for which RSV induces cell proliferation inhibition in colon cancer cell lines without toxicity in normal cells $[12,13,15]$. All control and treated cells received the same volume of ethanol $(0.1 \%)$. After the indicated times, cells were harvested and the number of viable cells was quantified with a hemocytometer by the trypan blue exclusion test as previously described [13].

\section{4. mRNA extraction and gene expression analysis by real-time qRT-PCR}

Total RNA from untreated SW480, SW620, HCT116 and Caco-2 cells were extracted using Trizol reagent (Invitrogen) according to the manufacturer's instructions. One microgram of RNA was reverse-transcribed using the M-MLV Reverse Transcriptase kit (Invitrogen) according to the manufacturer's instructions to produce cDNA. RT-qPCR was performed using the Power SYBR ${ }^{\circledR}$ Green PCR Master Mix kit (Applied Biosystems), according to the manufacturer's protocol, with a 7500 Fast Real-Time PCR system (Applied Biosystems). The following primers were used: $\beta$-actin (housekeeping gene) forward 5'CTTCCTGGGCATGGAGTC-3', reverse 5'- GCCAGGGTACATGGTGGT-3'; PPAR $\gamma 1$ : forward 5'-AAAGAAGCCAACACTAAACC-3', reverse 5'-CTTCCATTACGGAGAGATCC-3'; $P P A R \beta / \delta$ :forward 5'-TGGCTTTGTCACCCGTGAGT-3', reverse $5^{\prime}-$ CAGAATGATGCCGCAATGAA -3'; PPAR $\alpha$ : forward 5'-AGAACAAGGAGGCGGAGGT -3', reverse 5'-TCAGGTCCAAGTTTGCGAAGC -3'. Samples (triplicates for each cell line) were incubated at $95^{\circ} \mathrm{C}$ for 5 min for denaturation followed by 40 cycles of denaturation at $95^{\circ} \mathrm{C}$ for $15 \mathrm{~s}$ and combine annealing and extension at $60^{\circ} \mathrm{C}$ for $1 \mathrm{~min}$. Amplification of specific transcripts was confirmed by melting curves obtained at the end of each PCR run. Standard 
curves were generated from pooled cDNA of assayed samples. All PCR efficiencies were between 95 and 105\%. The relative changes in gene expression were determined using the $\Delta \Delta \mathrm{C}_{\mathrm{T}}$ method. Fold change was calculated as $2^{-{ }_{\Delta \Delta} \mathrm{CT}}$.

\subsection{Flow cytometric analysis of cell cycle}

Cells were seeded $24 \mathrm{~h}$ before treatment into $25-\mathrm{cm}^{2}$ flasks. After treatment, the detached and adherent cells were pooled, fixed with ethanol and stained with propidium iodide (PI) as previously described [17] for subsequent analyses with a CyFlow Green flow cytometer, and the fluorescence of PI was detected above $630 \mathrm{~nm}$. For each sample, 20,000 cells were acquired. Furthermore, data were analyzed with MultiCycle software (Phoenix Flow Systems, San Diego, CA, USA); the x-axis corresponds to the DNA content and the y-axis to the number of cycling cells. The maximum value on the y-axis is inversely proportionate to the altered cells level (non-cycling cells), which were excluded by gating.

\subsection{Apoptosis identification}

Cells were seeded into six-well plates $24 \mathrm{~h}$ before treatments. Then cells were untreated (Co) or treated with either RSV alone $(30$ or $50 \mu \mathrm{M})$ or in combination with PPAR $\gamma$ antagonist GW9662 $(5 \mu \mathrm{M})$ for $48 \mathrm{~h}$. Transiently transfected cells with either empty plasmid (pcDNA3) or a plasmid encoding a double dominant-negative mutant of PPAR $\gamma$ (PPAR $\gamma / \mathrm{DN})$ were treated $24 \mathrm{~h}$ after transfection with RSV at $30 \mu \mathrm{M}$ (R30) or $50 \mu \mathrm{M}$ (R50) or the vehicle (Co). After incubation time periods, supernatants of each well were collected and the adherent cells were recovered by trypsinization with $1 \mathrm{~mL}$ of trypsin/EDTA solution. Suspensions containing supernatant and trypsinized cells were washed with PBS $1 \mathrm{X}$ and then stained with $1 \mu \mathrm{g} / \mathrm{mL}$ Hoechst 33342 (Sigma-Aldrich) for $15 \mathrm{~min}$ at $37^{\circ} \mathrm{C}$. Cells were then mounted onto glass slides and observed with a light microscope (Zeiss, Germany). Percentages of apoptotic 
cells presenting typical nuclear chromatin condensation and fragmentation were determined by analyzing 300 cells from randomly selected fields.

\subsection{Immunofluorescence studies}

Tumor cells were seeded into tissue culture chambers at 20,000 per well (Chamber Slide, Life Technologies Co.) for $24 \mathrm{~h}$, then treated and subsequently fixed in $2 \%$ paraformaldehyde (Sigma-Aldrich, Chemical Co.) for $10 \mathrm{~min}$ at $4^{\circ} \mathrm{C}$, washed twice with PBS for $10 \mathrm{~min}$, preincubated with $1 \%$ bovine serum albumin for $15 \mathrm{~min}$ at room temperature, and incubated with the primary $\mathrm{Ab}$ (PBS, 0.1\% saponin, 0.5\% bovine serum albumin) for $2 \mathrm{~h}$ at room temperature. After washing, cells were incubated for $30 \mathrm{~min}$ with 488-alexa goat anti-rabbit (Molecular Probes, Eugene, OR, USA). Nuclei were stained with Hoechst 33342. Analysis was made using a fluorescence microscope (Nikon, Champigny, France). A nonrelevant isotype-matching $\mathrm{Ab}$ was used as negative control (not shown).

\subsection{Chemosensitization assays}

Colon cancer cells were seeded $24 \mathrm{~h}$ before treatment into $24-w e l l$ plates. The next day, cells were left untreated or pretreated in triplicate wells with RSV $(10 \mu \mathrm{M})$ for $24 \mathrm{~h}$ and then challenged for additional $24 \mathrm{~h}$ with rosiglitazone. We have previously shown that RSV at 10 $\mu \mathrm{M}$ was able to sensitize colon cancer cells to various chemical drugs $[12,18,19]$. After treatments, cells were washed with PBS and then stained with crystal violet $(0.5 \%(\mathrm{w} / \mathrm{v})$ for 5 min and then rinsed twice with water. Absorbance was read at $540 \mathrm{~nm}$ after extraction of the dye by $0.1 \mathrm{M}$ sodium citrate in $50 \%$ ethanol.

\subsection{Statistical analyses}


Data are expressed as means $\pm \mathrm{SD}(n=6)$ of at least three independent experiments. The significance of differences was established with Student's paired $t$-test. Values of $p<0.05$ were considered significant. 


\section{Results}

\subsection{Resveratrol-induced colon cancer cell death is prevented by PPAR $\gamma$ antagonists or by PPAR $\gamma$ dominant-negative expression.}

We exposed four human colon cancer cell lines, namely Caco-2, HCT-116, SW480 and their metastatic phenotype SW620 to $30 \mu \mathrm{M}$ RSV for $24 \mathrm{~h}$ before evaluating cell viability (Fig. 1A). The RSV concentration was chosen in agreement with our previous results showing a marked antiproliferative and proapoptotic effect on various tumor cell lines $[12,17,20]$ without any toxic effect on normal human monocytes and rat intestinal IEC18 cells [15]. As revealed by the trypan blue exclusion viability test, $30 \mu \mathrm{M}$ RSV (R30) strongly decreases cell viability of the four tumor cell lines, in as little as $24 \mathrm{~h}$ and is reinforced at $48 \mathrm{~h}$ (Fig. 1A).

In order to analyze the potential role of PPAR $\gamma$ in the antiproliferative activity of RSV in colon cancer cells, we used the potent irreversible and selective PPAR $\gamma$ antagonist 2chloro-5-nitrobenzanilide (GW9662) in the presence and absence of RSV (Fig. 1A). As GW9662 itself has growth-inhibitory properties [21], we used it at 2.5 and $5 \mu \mathrm{M}$, concentrations where GW9662 acts as a potent antagonist of PPAR $\gamma$ in the cell [22]. GW9662 covalently modifies Cys(285) and does not affect the transcription of full-length PPAR $\alpha$ and PPAR $\delta$ and consequently does not interfere with the signaling pathways modulated by $\operatorname{PPAR} \alpha$ and $\operatorname{PPAR} \delta[21,22]$. This PPAR $\gamma$ inhibitor dose-dependently prevented RSV-induced death of the four colon cancer cell lines in the same manner at 24 and $48 \mathrm{~h}$ (Fig. 1A). Interestingly, increasing the concentration of GW9662 up to $5 \mu \mathrm{M}$ in Caco-2 cells further inhibited RSV-induced cell death, which was not observed with the other cell lines where no differences were seen between $2.5 \mu \mathrm{M}$ or $5 \mu \mathrm{M}$ of PPAR $\gamma$ antagonist (Fig. 1A). These differences were strengthened at $48 \mathrm{~h}$ of treatment. Indeed, it seems that in SW480, S620 and HCT116 cells, PPAR $\gamma$ is yet fully blocked by $2.5 \mu \mathrm{M}$ of GW9662, whereas dose-dependent inhibition is observed in Caco-2 cells with pronounced differences between 2.5 and $5 \mu \mathrm{M}$ 
(Fig. 1A). A potential explanation could be provided by the analyses of PPAR expression levels in the different cell lines tested. Indeed, qPCR analyses show that compared to the three other cell lines, Caco-2 cells express PPAR $\gamma$ more strongly, as revealed by the mRNA levels (Supporting information Fig. S1). This result may explain why a concentration-dependent effect is more visible in Caco-2 cells than in the other tumor cell lines (SW480, SW620 and HCT116) after $48 \mathrm{~h}$ of treatment, where the nuclear factor PPAR $\gamma$ is probably saturated by the antagonist GW9662.

To further assess the role of PPAR $\gamma$ in this death pathway, we transiently transfected SW480 colon cancer cells with constructs encoding a double dominant-negative mutant of PPAR $\gamma$ that retains its ligand and DNA-binding properties [16]. We showed that transient expression of PPAR $\gamma / \mathrm{DN}$ protects colon cancer cells from RSV-induced cell death (Fig. 1B) to a similar extent as $5 \mu \mathrm{M}$ GW9662 (Fig. 1A). Notably, these cell lines also express PPAR $\alpha$ or PPAR $\beta / \delta$ (Supporting information Fig. S1). Indeed, quantification by qPCR of the different PPARs shows that PPAR $\alpha$ or PPAR $\beta / \delta$ is also expressed in all cell lines tested. Despite the expression of PPAR $\alpha$ or PPAR $\beta / \delta$, selective chemical antagonists of these receptors, respectively GW6471 and GSK0660, did not prevent their death induced by exposure to RSV (Fig. 1C). Similar results were obtained in the metastatic SW620 cell line where PPAR $\gamma / \mathrm{DN}$ decreases the number of SW620 cells from RSV-induced cell death (Supporting information Fig. S2A).

\subsection{Resveratrol-induced cell cycle arrest is prevented by PPAR $\gamma$ chemical inhibition.}

We have previously shown that RSV, like many cytotoxic agents, affects cell proliferation by disturbing the normal progress of the cell cycle $[12,20]$, especially by accumulation of colon cancer SW480 in the S phase $[12,13,17]$. To further dissect the PPAR $\gamma$-involving pathway that leads to colon cancer cell death upon RSV exposure, we 
explored the cell cycle effect of the drugs alone or in combination. As expected, after $48 \mathrm{~h}$ of treatment with $30 \mu \mathrm{M}$ of RSV alone, a high proportion ( 45\%) of colon cancer SW480 cells that are still alive accumulate in the $\mathrm{S}$ phase of the cell cycle (Fig. 2A). Interestingly, combining GW9662 $(5 \mu \mathrm{M})$ with RSV (R30) decreased the percentage of living cells in the DNA replication phase of the cell cycle from 45 to 20\% (Fig. 2B). Similarly, RSV strongly accumulates metastatic SW620 cells in the S phase, which is slightly reduced by a combination with GW9662 (5 $\mu \mathrm{M})$ (Supporting information Fig. S2B).

\subsection{PPAR $\gamma$ antagonist inhibits resveratrol-induced apoptosis}

To investigate the death of colon cancer cells induced by RSV, we determined the process of apoptosis. We have previously shown in various colon cancer cells, e.g., SW480 and SW620 cells, that RSV was able to lead to caspase-3 activation and subsequently to induce apoptosis in a dose-dependent manner [14, 18]. Cell staining with Hoechst 33342 demonstrated that after $48 \mathrm{~h}$ of treatment, RSV induced a dose-dependent increase (30-50 $\mu \mathrm{M})$ in the cancer cell nucleus size, which preceded the appearance of characteristic apoptotic changes, i.e., the condensation and fragmentation of the nuclear chromatin in SW480 (Fig. 3A, B) and SW620 cells (Supporting information Fig. S2C). These nuclear changes were inhibited by cotreatment with the PPAR $\gamma$ antagonist GW9662 (Fig. 3A, B; Supporting information Fig. S2C), leading to a decrease in RSV-induced apoptosis of colon cancer cells either at 30 or $50 \mu \mathrm{M}$ RSV (Fig. 3B; Supporting information Fig. S2C). Moreover, transfection of SW480 cells or their metastatic SW620 cells with constructs encoding PPAR $\gamma / \mathrm{DN}$ protects colon cancer cells from RSV-induced apoptosis (Fig. 3C; Supporting information Fig. S2C) to the same extent as $5 \mu \mathrm{M}$ of GW9662 (Fig. 3B). As we have previously demonstrated that in these colon cancer cells [11, 21] RSV-induced apoptosis involves caspase-3 activation (Fig. 3D, E). First, using an antibody (Ab) that specifically 
detects the active form of the caspase- 3 protease, with immunofluorescence we demonstrated that GW9662 prevents caspase-3 activation induced by RSV in SW480 apoptotic cells (Fig. 3D). Secondly, the activation of caspase-3 was confirmed by flow cytometry (Fig. 3E). These results support the notion that PPAR $\gamma$ is critical to mediate the death process induced by RSV.

\subsection{Resveratrol combined with the PPAR $\gamma$ agonist rosiglitazone increases colon cancer cell apoptosis}

We have previously reported that RSV at a low concentration $(10 \mu \mathrm{M})$ is able to sensitize carcinoma SW480 cells to various chemical drugs through the arrest of the cell cycle and the induction of apoptosis $[12,18,19]$. Since RSV-induced apoptosis involves, at least in part, PPAR $\gamma$, the polyphenol could sensitize colon cancer cells to PPAR $\gamma$ agonists. Furthermore, PPAR $\gamma$ ligands were demonstrated to inhibit growth and induce apoptosis of various tumor cell types [23]. However, one of the PPAR $\gamma$ agonists, rosiglitazone, has limited effects on colon cancer cell proliferation and death, up to $5 \mu \mathrm{M}$ [24]. We therefore examined whether RSV at $10 \mu \mathrm{M}$ could sensitize colon cancer cells to the potential antitumor effects of rosiglitazone at 1 and $5 \mu \mathrm{M}$. To explore the potential synergism induced by RSV, we pretreated colon cancer cells for $24 \mathrm{~h}$ with RSV at $10 \mu \mathrm{M}$ and we then exposed tumor cells for $24 \mathrm{~h}$ to the PPAR $\gamma$ agonist rosiglitazone $(1$ or $5 \mu \mathrm{M})$ before assessment of apoptosis. The drug combination was observed to be more efficient than the addition of each drug activity, as indicated by measuring the percentage of surviving cells (Fig. 4A) and that of apoptotic cells. As expected, we observed that rosiglitazone exerts a small effect on colon cancer cell viability at the concentrations used ( 1 and $5 \mu \mathrm{M})$ (Fig. 4A). Polyphenolic pretreatment primes the cell for the action of the PPAR $\gamma$ agonist rosiglitazone to kill the cancer cell in a dose-dependent manner (Fig. 4A). Similar results were obtained with other PPAR $\gamma$ agonists, (e.g. troglitazone) but it appears clearly that the best synergy is the combination with rosigltiazone 
to kill colon cancer cells (Fig. 4A, Supporting information Fig. S3). The increase of cell death induced by the combination of PPAR $\gamma$ agonist and RSV is associated with an enhancement of apoptosis in these cells. Indeed, we observed an increase of the percentage of apoptotic cells (Fig. 4B) together with an increase of caspase-3 activation (Fig. 4C), as revealed by the enhancement of the green fluorescence with an Ab against the active form of caspase- 3 in fluorescence microscopy. 


\section{Discussion}

The present study indicates that the ability of RSV to trigger colorectal cancer cell apoptosis involves the nuclear receptor PPAR $\gamma$. These events contribute to the sensitizing effect of RSV to the PPAR $\gamma$ agonist (rosiglitazone), where a combination of RSV/PPAR $\gamma$ agonist exhibits greater apoptosis induction than RSV alone in colon cancer cells.

It has been clearly demonstrated that RSV exerts a variety of biological activities and its antioxidant and chemopreventive effects are currently evaluated in a variety of human diseases including cancer $[5,6]$. As for the cancer chemopreventive action, RSV has been shown to impair every stage of the carcinogenic process $[25,26]$. These preventive actions of RSV have been extensively studied at the molecular and cellular level, such as cellular signaling, enzymatic pathways, apoptosis and gene expression [27-29], but due to the pleiotropic action of RSV, the underlying molecular mechanisms are only partially understood. Indeed, we have recently shown that RSV-induced apoptosis in colon cancer cells involved a RSV endocytosis mechanism that is dependent on lipid rafts and constitutes the initial events of RSV effects [15]. At the molecular level, MAPK/integrin $\alpha_{\mathrm{v}} \beta_{3}$ complexes are activated, leading to modulation of different pathways that play important roles in apoptosis induced by RSV [15]. Nevertheless, a disruption of lipid rafts and an inhibition of the integrin $\alpha_{v} \beta_{3}$ did not completely abolish the effect of RSV, suggesting that there are other actors playing a role in the molecular effect.

Since RSV was shown to activate the SSAT enzyme involved in polyamine catabolism through the nuclear transcription factor PPAR $\gamma$ [8], we sought to explore the role of this receptor in RSV-induced apoptosis of colon cancer cells. PPAR $\gamma$ is a member of the nuclear hormone receptor superfamily of ligand-activated transcription factors that play a critical role in the regulation of multiple cellular processes including energy metabolism, cell differentiation and cell proliferation [30, 31]. Previous studies have shown that PPAR $\gamma$ can 
function as a tumor suppressor, and its ligand has promising antitumor activity in preclinical models [23, 32-35]. In the present work, our results showed that RSV inhibits colon cancer cell viability through a PPAR $\gamma$-dependent pathway. Indeed, an irreversible and selective PPAR $\gamma$ antagonist, GW9662, which covalently modifies a cysteine residue in the ligandbinding site of PPAR $\gamma$ [22], partly prevents RSV-induced colon cancer cell death. To further confirm the involvement of PPAR $\gamma$ in this effect, SW480 colon cancer cells were transfected by a dominant-negative mutant form of PPAR $\gamma(\operatorname{PPAR} \gamma / \mathrm{DN})$ in which two conserved hydrophobic and charged residues $\left(\mathrm{Leu}^{468}\right.$ and $\mathrm{Glu}^{471}$ ) in helix 12 of the ligand-binding domain were mutated to alanine [16]. Importantly, PPAR $\gamma / \mathrm{DN}$ retains ligand and DNAbinding activity, but exhibits markedly reduced transactivation due to impaired coactivator recruitment [16]. In a manner similar to GW9662, transient expression of PPAR $\gamma / \mathrm{DN}$ reduces the antiproliferative effect of RSV in colon carcinoma cells. Besides PPAR $\gamma$, PPAR $\alpha$ and PPAR $\beta / \delta$ isoforms are also involved in the regulation of differentiation, cell proliferation and apoptosis [36]. However, RSV-induced cell death involves only PPAR $\gamma$ and not the two PPAR $\alpha$ and PPAR $\beta / \delta$ isoforms, as proved by the use of their respective antagonists. As we have previously shown in various cancer cell lines, RSV affects cell viability by disturbing the normal progress of the cell cycle in the S phase $[12,13,17]$.

Actually, it is well known that PPAR $\gamma$ agonists modulate expression of different key regulators involved in cell cycle progression $[33,37]$. It appears that the combination of a PPAR $\gamma$ antagonist with RSV can prevent, although not completely, the accumulation of colorectal cancer cells in the DNA replication phase. Cells that accumulate in the S phase are no longer able to divide, and consequently will evolve toward cell death through a RSVinduced apoptosis and caspase-3 activation, as previously described [12-14, 17] 
Cotreatment with the PPAR $\gamma$ antagonist GW9662 leads to a decrease of RSV-induced caspase activation and subsequently apoptosis of colon cancer cells. These results were strengthened by the use of transiently transfected SW480 cells with the PPAR $\gamma / \mathrm{DN}$ mutant.

Previous reports have established that PPAR $\gamma$ agonists were able to induce apoptosis in some cancer cell types through an increase of pro-apoptotic Bax and Bak protein expression, an inhibition of Bcl- $\mathrm{x}_{\mathrm{L}}$ and $\mathrm{Bcl}-2$ function, or an inhibition of Jun $\mathrm{N}$-terminal protein kinase activation [33, 38, 39]. Many of these changes increase caspase activity and apoptosis. Moreover, others have previously reported that PPAR agonists exhibit antitumor effects [30, 31] by inhibiting the growth of various tumor cells [23] or by inducing apoptosis [40]. The clinical trials to date have yielded evidence suggesting that PPAR $\gamma$ may be suitable for targeting in pre-cancerous and cancer cells in select tumor types. Thus, pretreatment of colon tumor cells with RSV synergizes with PPAR agonist to induce cancer cell death. Altogether, PPAR $\gamma$ could mediate a part of the chemopreventive activity of RSV in colon cancer and the combination of RSV with PPAR $\gamma$ modulators.

The screening and identification of natural compounds that retain PPAR $\gamma$-dependent and/or PPAR $\gamma$-independent anti-cancer activities could be a useful approach [41, 42]. Alternatively, development of "non-agonist" modulators of PPAR $\gamma$ that exhibit improved safety profiles [43] might be a suitable strategy to explore. 


\section{Acknowledgements:}

This work was supported by the Ligue Inter-régionale Grand-Est Contre le Cancer. A.S. received a post-doctoral fellowship from the "Conseil Régional de Bourgogne" and we thank the FEDER for its support to the DD group.

\section{Conflict of interest}

The authors declare that they have no conflict of interest. 


\section{References}

[1] Lin, I. H., Ho, M. L., Chen, H. Y., Lee, H. S., et al., Smoking, green tea consumption, genetic polymorphisms in the insulin-like growth factors and lung cancer risk. PLoS One 2012, 7, e30951.

[2] Sun, C. L., Yuan, J. M., Koh, W. P., Yu, M. C., Green tea, black tea and breast cancer risk: a meta-analysis of epidemiological studies. Carcinogenesis 2006, 27, 1310-1315.

[3] Surh, Y. J., Cancer chemoprevention with dietary phytochemicals. Nat Rev Cancer 2003, $3,768-780$.

[4] Renaud, S. C., Gueguen, R., Schenker, J., d'Houtaud, A., Alcohol and mortality in middleaged men from eastern France. Epidemiology 1998, 9, 184-188.

[5] Delmas, D., Solary, E., Latruffe, N., Resveratrol, a phytochemical inducer of multiple cell death pathways: apoptosis, autophagy and mitotic catastrophe. Curr Med Chem 2011, 18, $1100-1121$.

[6] Baur, J. A., Sinclair, D. A., Therapeutic potential of resveratrol: the in vivo evidence. Nat Rev Drug Discov 2006, 5, 493-506.

[7] Juan, M. E., Alfaras, I., Planas, J. M., Colorectal cancer chemoprevention by transresveratrol. Pharmacol Res 2012, 65, 584-591.

[8] Ulrich, S., Loitsch, S. M., Rau, O., von Knethen, A., et al., Peroxisome ProliferatorActivated Receptor \{gamma\} as a Molecular Target of Resveratrol-Induced Modulation of Polyamine Metabolism. Cancer Res 2006, 66, 7348-7354.

[9] Alfaras, I., Juan, M. E., Planas, J. M., trans-Resveratrol reduces precancerous colonic lesions in dimethylhydrazine-treated rats. J Agric Food Chem 2010, 58, 8104-8110.

[10] Tessitore, L., Davit, A., Sarotto, I., Caderni, G., Resveratrol depresses the growth of colorectal aberrant crypt foci by affecting bax and p21(CIP) expression. Carcinogenesis 2000, $21,1619-1622$. 
[11] Patel, K. R., Brown, V. A., Jones, D. J., Britton, R. G., et al., Clinical pharmacology of resveratrol and its metabolites in colorectal cancer patients. Cancer Res 2010, 70, 7392-7399. [12] Colin, D., Gimazane, A., Lizard, G., Izard, J. C., et al., Effects of resveratrol analogs on cell cycle progression, cell cycle associated proteins and 5fluoro-uracil sensitivity in human derived colon cancer cells. Int J Cancer 2009, 124, 2780-2788.

[13] Marel, A. K., Lizard, G., Izard, J. C., Latruffe, N., Delmas, D., Inhibitory effects of transresveratrol analogs molecules on the proliferation and the cell cycle progression of human colon tumoral cells. Mol Nutr Food Res 2008, 52, 538-548.

[14] Delmas, D., Rebe, C., Lacour, S., Filomenko, R., et al., Resveratrol-induced apoptosis is associated with Fas redistribution in the rafts and the formation of a death-inducing signaling complex in colon cancer cells. J Biol Chem 2003, 278, 41482-41490.

[15] Colin, D., Limagne, E., Jeanningros, S., Jacquel, A., et al., Endocytosis of resveratrol via lipid rafts and activation of downstream signaling pathways in cancer cells. Cancer Prev Res (Phila) 2011, 4, 1095-1106.

[16] Gurnell, M., Wentworth, J. M., Agostini, M., Adams, M., et al., A dominant-negative peroxisome proliferator-activated receptor gamma (PPARgamma) mutant is a constitutive repressor and inhibits PPARgamma-mediated adipogenesis. J Biol Chem 2000, 275, 57545759.

[17] Delmas, D., Passilly-Degrace, P., Jannin, B., Malki, M. C., Latruffe, N., Resveratrol, a chemopreventive agent, disrupts the cell cycle control of human SW480 colorectal tumor cells. Int J Mol Med 2002, 10, 193-199.

[18] Delmas, D., Rebe, C., Micheau, O., Athias, A., et al., Redistribution of CD95, DR4 and DR5 in rafts accounts for the synergistic toxicity of resveratrol and death receptor ligands in colon carcinoma cells. Oncogene 2004, 23, 8979-8986. 
[19] Aires, V., Limagne, E., Cotte, A. K., Latruffe, N., et al., Resveratrol metabolites inhibit human metastatic colon cancer cells progression and synergize with chemotherapeutic drugs to induce cell death. Mol Nutr Food Res 2013.

[20] Delmas, D., Jannin, B., Malki, M. C., Latruffe, N., Inhibitory effect of resveratrol on the proliferation of human and rat hepatic derived cell lines. Oncol Rep 2000, 7, 847-852.

[21] Seargent, J. M., Yates, E. A., Gill, J. H., GW9662, a potent antagonist of PPARgamma, inhibits growth of breast tumour cells and promotes the anticancer effects of the PPARgamma agonist rosiglitazone, independently of PPARgamma activation. Br. J. Pharmacol. 2004, 143, 933-937.

[22] Leesnitzer, L. M., Parks, D. J., Bledsoe, R. K., Cobb, J. E., et al., Functional consequences of cysteine modification in the ligand binding sites of peroxisome proliferator activated receptors by GW9662. Biochemistry 2002, 41, 6640-6650.

[23] Mueller, E., Smith, M., Sarraf, P., Kroll, T., et al., Effects of ligand activation of peroxisome proliferator-activated receptor gamma in human prostate cancer. Proc Natl Acad Sci U S A 2000, 97, 10990-10995.

[24] Cerbone, A., Toaldo, C., Minelli, R., Ciamporcero, E., et al., Rosiglitazone and AS601245 decrease cell adhesion and migration through modulation of specific gene expression in human colon cancer cells. PLoS One 2012, 7, e40149.

[25] Jang, M., Cai, L., Udeani, G. O., Slowing, K. V., et al., Cancer chemopreventive activity of resveratrol, a natural product derived from grapes. Science 1997, 275, 218-220.

[26] Ahmad, N., Katiyar, S. K., Mukhtar, H., Antioxidants in chemoprevention of skin cancer. Curr Probl Dermatol 2001, 29, 128-139.

[27] Kroon, P. A., Iyer, A., Chunduri, P., Chan, V., Brown, L., The Cardiovascular Nutrapharmacology of Resveratrol: Pharmacokinetics, Molecular Mechanisms and Therapeutic Potential. Curr Med Chem 2010, 17, 2442-2455. 
[28] Shih, A., Zhang, S., Cao, H. J., Boswell, S., et al., Inhibitory effect of epidermal growth factor on resveratrol-induced apoptosis in prostate cancer cells is mediated by protein kinase C-alpha. Mol Cancer Ther 2004, 3, 1355-1364.

[29] Lin, H. Y., Shih, A., Davis, F. B., Tang, H. Y., et al., Resveratrol induced serine phosphorylation of p53 causes apoptosis in a mutant p53 prostate cancer cell line. J Urol $2002,168,748-755$.

[30] Heaney, A. P., Fernando, M., Melmed, S., PPAR-gamma receptor ligands: novel therapy for pituitary adenomas. $J$ Clin Invest 2003, 111, 1381-1388.

[31] Yoshimura, R., Matsuyama, M., Segawa, Y., Hase, T., et al., Expression of peroxisome proliferator-activated receptors (PPARs) in human urinary bladder carcinoma and growth inhibition by its agonists. Int. J. Cancer 2003, 104, 597-602.

[32] Michalik, L., Desvergne, B., Wahli, W., Peroxisome-proliferator-activated receptors and cancers: complex stories. Nat Rev Cancer 2004, 4, 61-70.

[33] Peters, J. M., Shah, Y. M., Gonzalez, F. J., The role of peroxisome proliferator-activated receptors in carcinogenesis and chemoprevention. Nat Rev Cancer 2012, 12, 181-195.

[34] Koeffler, H. P., Peroxisome proliferator-activated receptor gamma and cancers. Clin Cancer Res 2003, 9, 1-9.

[35] Sarraf, P., Mueller, E., Jones, D., King, F. J., et al., Differentiation and reversal of malignant changes in colon cancer through PPARgamma. Nat Med 1998, 4, 1046-1052.

[36] Lamers, C., Schubert-Zsilavecz, M., Merk, D., Therapeutic modulators of peroxisome proliferator-activated receptors (PPAR): a patent review (2008-present). Expert Opin Ther Pat $2012,22,803-841$.

[37] Roberts-Thomson, S. J., Peroxisome proliferator-activated receptors in tumorigenesis: targets of tumour promotion and treatment. Immunol. Cell Biol. 2000, 78, 436-441. 
[38] Bae, M. A., Song, B. J., Critical role of c-Jun N-terminal protein kinase activation in troglitazone-induced apoptosis of human HepG2 hepatoma cells. Mol Pharmacol 2003, 63, 401-408.

[39] Farrow, B., Evers, B. M., Activation of PPARgamma increases PTEN expression in pancreatic cancer cells. Biochem Biophys Res Commun 2003, 301, 50-53.

[40] Nagamine, M., Okumura, T., Tanno, S., Sawamukai, M., et al., PPAR gamma ligandinduced apoptosis through a p53-dependent mechanism in human gastric cancer cells. Cancer Sci 2003, 94, 338-343.

[41] Zhang, Q., Zhou, H., Zhai, S., Yan, B., Natural product-inspired synthesis of thiazolidine and thiazolidinone compounds and their anticancer activities. Curr. Pharm. Des. 2010, 16, 1826-1842.

[42] Wei, S., Yang, J., Lee, S. L., Kulp, S. K., Chen, C. S., PPARgamma-independent antitumor effects of thiazolidinediones. Cancer Lett. 2009, 276, 119-124.

[43] Choi, J. H., Banks, A. S., Kamenecka, T. M., Busby, S. A., et al., Antidiabetic actions of a non-agonist PPARgamma ligand blocking Cdk5-mediated phosphorylation. Nature 2011, $477,477-481$. 


\section{Figure legends}

Figure 1. RSV inhibits colon cancer cell survival through a PPAR $\gamma$ pathway. (A) After $24 \mathrm{~h}$ of culture, colon cancer cell lines, HCT-116, Caco-2 and SW480 and their metastatic phenotype SW620 cells were left untreated (Co, $0.1 \%$ ethanol) or treated with RSV at $30 \mu \mathrm{M}$ (R30) with or without GW9662 at 2.5 (GW2.5) or 5 (GW5) $\mu \mathrm{M}$ for the indicated times, and the percentage of cell survival was determined using trypan blue exclusion. (B) SW480 cells were transiently transfected with either an empty plasmid (pcDNA3) or a plasmid encoding a double dominant-negative mutant of PPAR $\gamma(\operatorname{PPAR} \gamma / \mathrm{DN})$. Twenty-four hours later, cells were treated with either $30 \mu \mathrm{M}$ of RSV (R30) or with the vehicle (Co, $0.1 \%$ ethanol) for $48 \mathrm{~h}$ before measuring cell survival. (C) SW480 cells were left untreated (black bars) or treated with RSV at $30 \mu \mathrm{M}$ (R30) (white bars) with or without the PPAR $\alpha$ antagonist, GW6471 or the PPAR $\beta / \delta$ antagonist, GSK0660 at indicated concentrations $(0-5 \mu \mathrm{M})$ for $48 \mathrm{~h}$. Cell survival was measured by trypan blue exclusion. All panels: mean $\pm \operatorname{SD}(n=6)$ of three independent experiments; ${ }^{*}, p<0.05$ and ${ }^{* *}, p<0.001$.

Figure 2. Accumulation of tumor cells in the S phase by RSV is prevented by PPAR $\gamma$ antagonist. (A). After $24 \mathrm{~h}$ of culture, colon cancer SW480 cells were left untreated or treated for $48 \mathrm{~h}$ with RSV at $30 \mu \mathrm{M}$ (R30) with or without $5 \mu \mathrm{M}$ of GW9662, then stained with PI and analyzed by flow cytometry. One experiment representative of three is shown. (B) Quantitative analysis of colon cancer SW480 cell distribution in the phases of the cell cycle (mean \pm SD of three independent experiments). 
Figure 3. PPAR $\gamma$ contributes to RSV-induced apoptosis in colon cancer cells. (A). SW480 cells were left untreated (Co) or treated with $30 \mu \mathrm{M}$ RSV for $48 \mathrm{~h}$ (R30) in the absence or presence of $5 \mu \mathrm{M}$ GW9662 (GW5) before nuclear staining with Hoechst 33342. Original magnification: $\times 40$. (B) SW480 cells were left untreated or treated for $48 \mathrm{~h}$ with RSV at 30 (R30) or $50 \mu \mathrm{M}$ (R50) with or without $5 \mu \mathrm{M}$ of GW9662 before Hoechst 33342 staining of a pool of detached and attached cells. The results are expressed as the percentage of apoptotic cells (mean \pm SE of three independent experiments in which each percentage was calculated by counting 300 cells). (C) SW480 cells were transiently transfected with an empty plasmid (pcDNA3) or a plasmid encoding a double dominant-negative mutant of PPAR $\gamma(\operatorname{PPAR} \gamma / \mathrm{DN})$ and treated $24 \mathrm{~h}$ later with RSV at $30 \mu \mathrm{M}(\mathrm{R} 30)$ or $50 \mu \mathrm{M}(\mathrm{R} 50)$ or the vehicle (Co) before measuring the percentage of apoptotic cells (mean $\pm \mathrm{SD}$ of three independent experiments in which each percentage was calculated by counting 300 cells). (D) SW480 cells were treated for $48 \mathrm{~h}$ as in $(\mathrm{C})$, before staining with an anti-active caspase-3 Ab (C3a) (green) with nuclei counterstained with Hoechst 33342 (blue). The arrow indicates a typical apoptotic cell. Original magnification: $\times 40$. (E) Caspase-3 activation was studied using an $\mathrm{Ab}$ that specifically recognizes the active form of the enzyme and analyzed using flow cytometry (gray, control; black line, treated cells). One experiment representative of three is shown.

Figure 4. RSV combination with rosiglitazone, a PPAR $\gamma$ agonist, increases colon cancer cell death. (A). SW480 cells were left untreated (Co) or treated for $24 \mathrm{~h}$ with $10 \mu \mathrm{M}$ of RSV, then exposed for $24 \mathrm{~h}$ to the PPAR $\gamma$ agonist rosiglitazone ( 1 or $5 \mu \mathrm{M}$ ) before counting the percentage of viable cells after crystal violet staining ( $n=6$, three independent experiments). *, $p<0.05$. (B) As above, SW480 cells were left untreated or treated for $24 \mathrm{~h}$ with RSV at $10 \mu \mathrm{M}$ (R10) and then exposed for $24 \mathrm{~h}$ to the PPAR $\gamma$ agonist rosiglitazone (1 or $5 \mu \mathrm{M})$ before 
assessment of apoptosis in a pool of detached and attached cells stained with Hoechst 33342. The results are expressed as the percentage of apoptotic cells (mean $\pm \mathrm{SD}$ of three independent experiments in which each percentage was calculated by counting 300 cells). (C) RSV/rosiglitazone combination synergizes to induce caspase-3 activation. Active caspase-3 was assigned the color green and nuclei labeled with Hoechst 33342 were assigned the color blue. The arrow indicates a typical apoptotic cell. Representative cells of three independent experiments are shown. Original magnification: $\times 40$. 
Figure 1, Aires et al.,

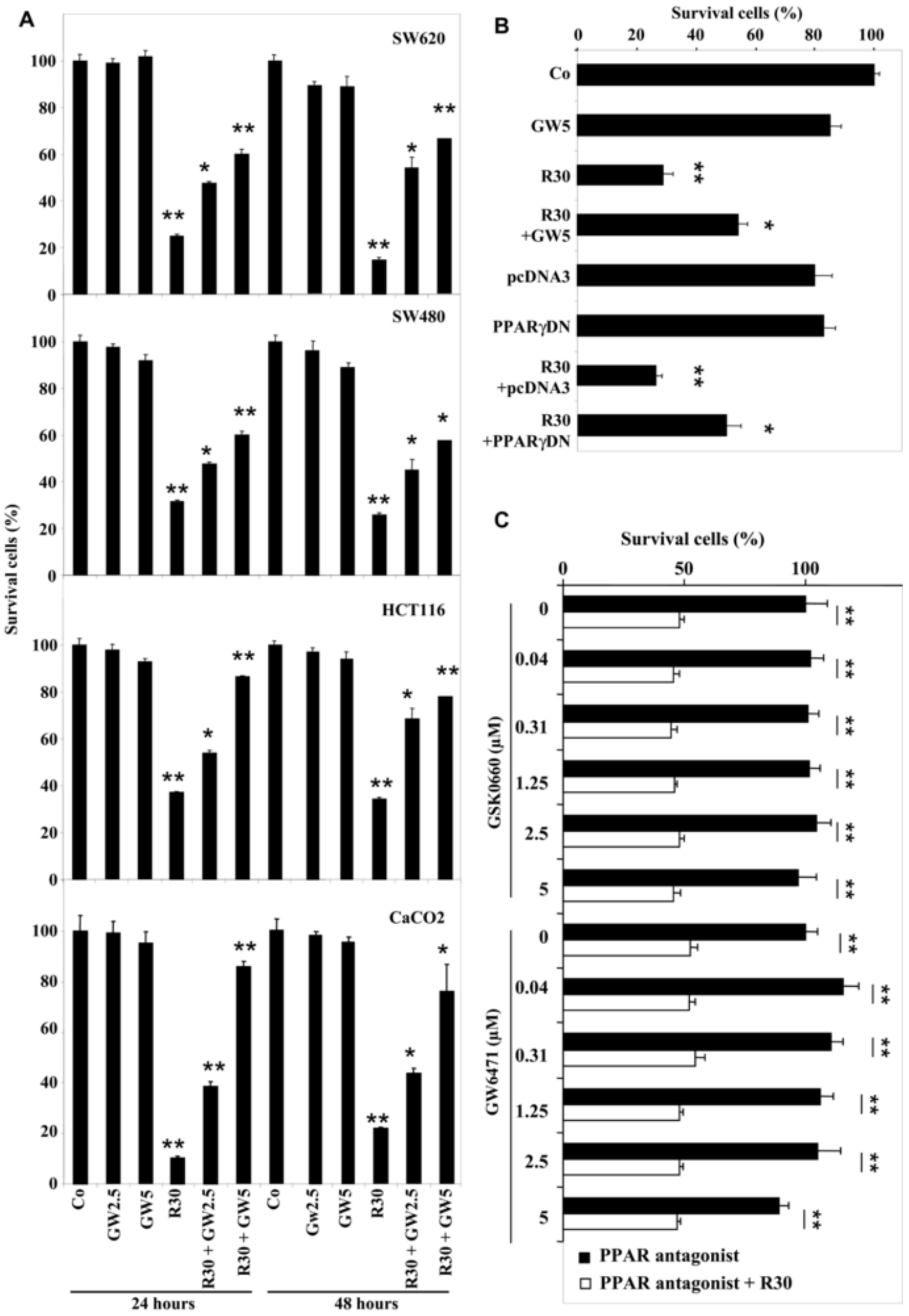


Figure 2 Aires et al.,

A)

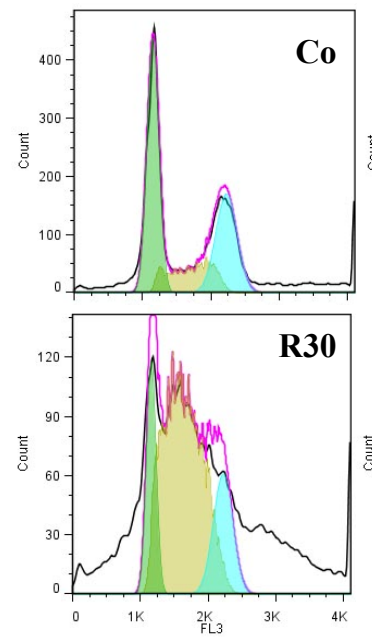

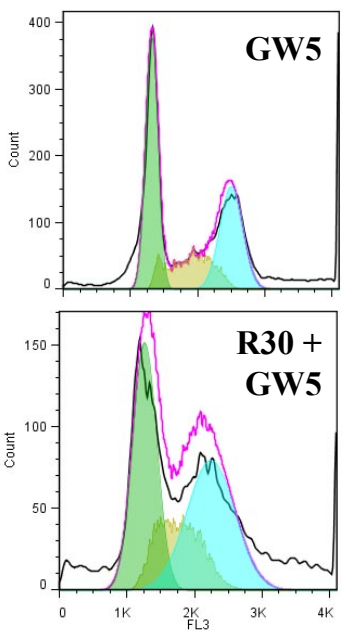

B)

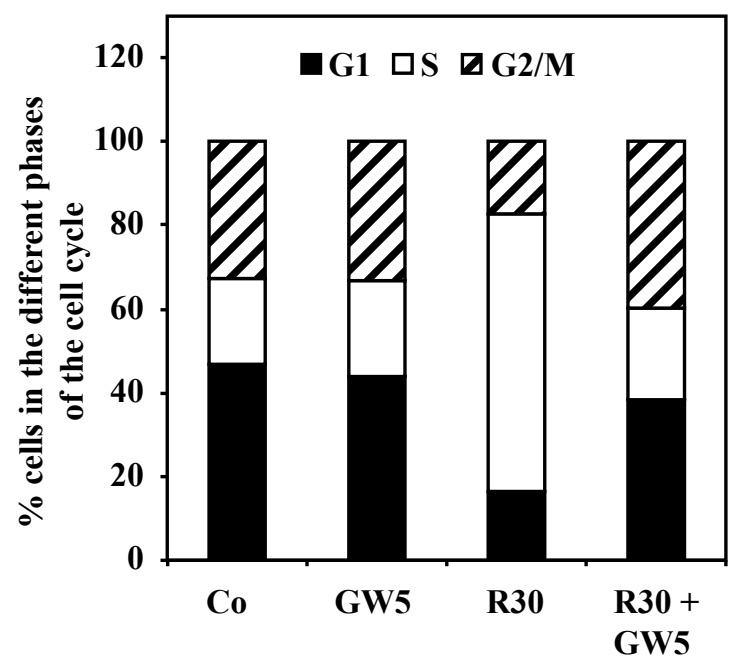


Figure 3 Aires et al.,

A)

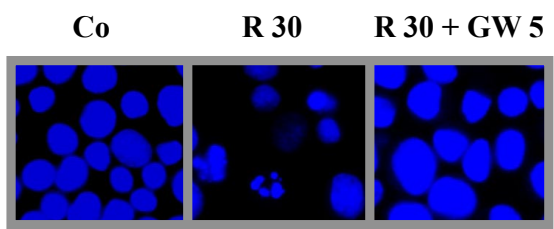

B)

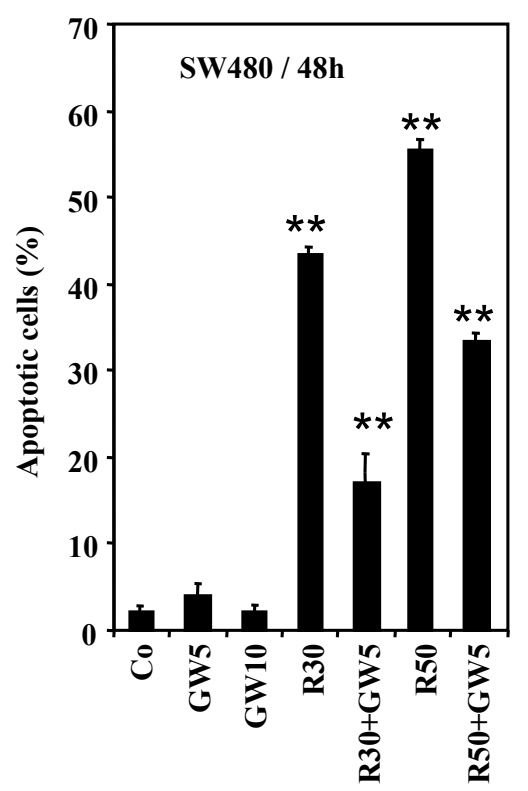

D)

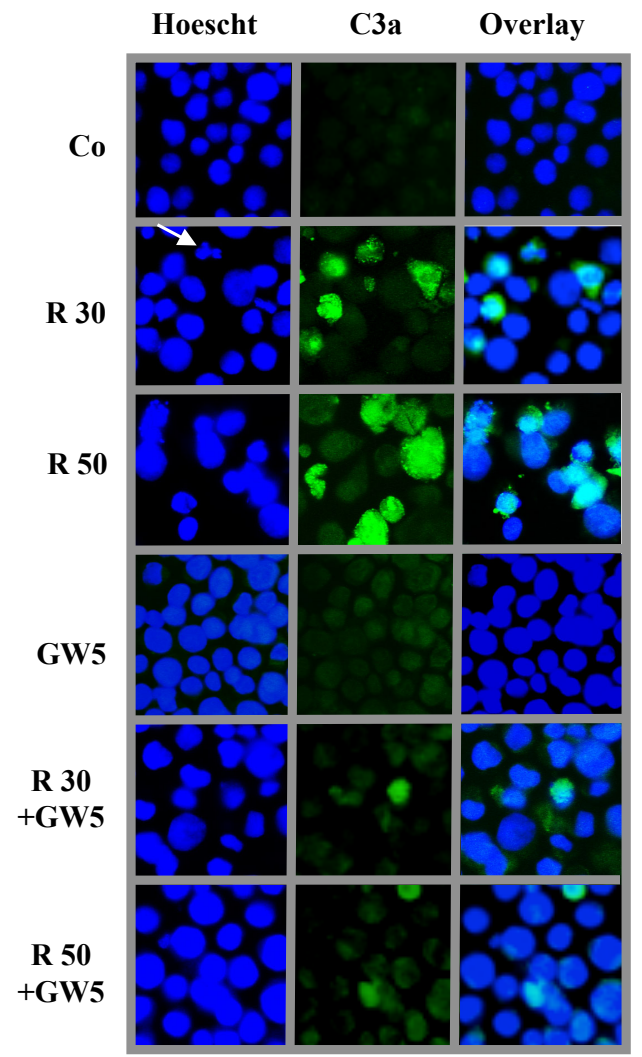

C)

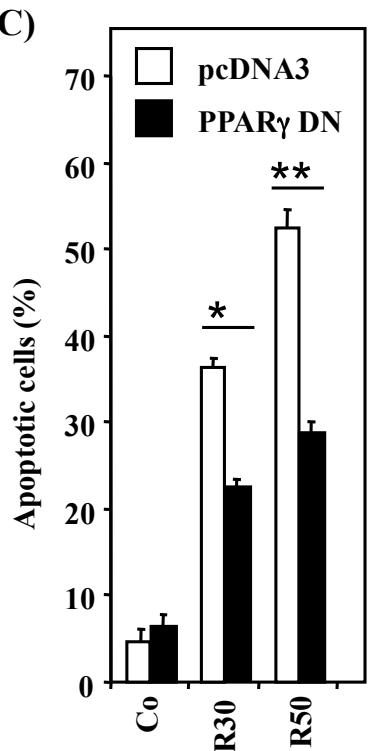

E)

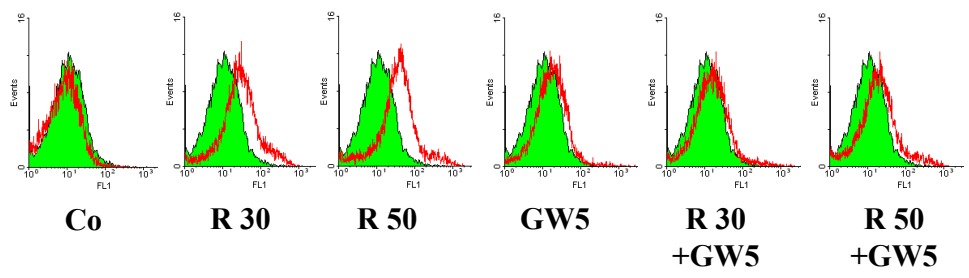


Figure 4 Aires et al.,

A)

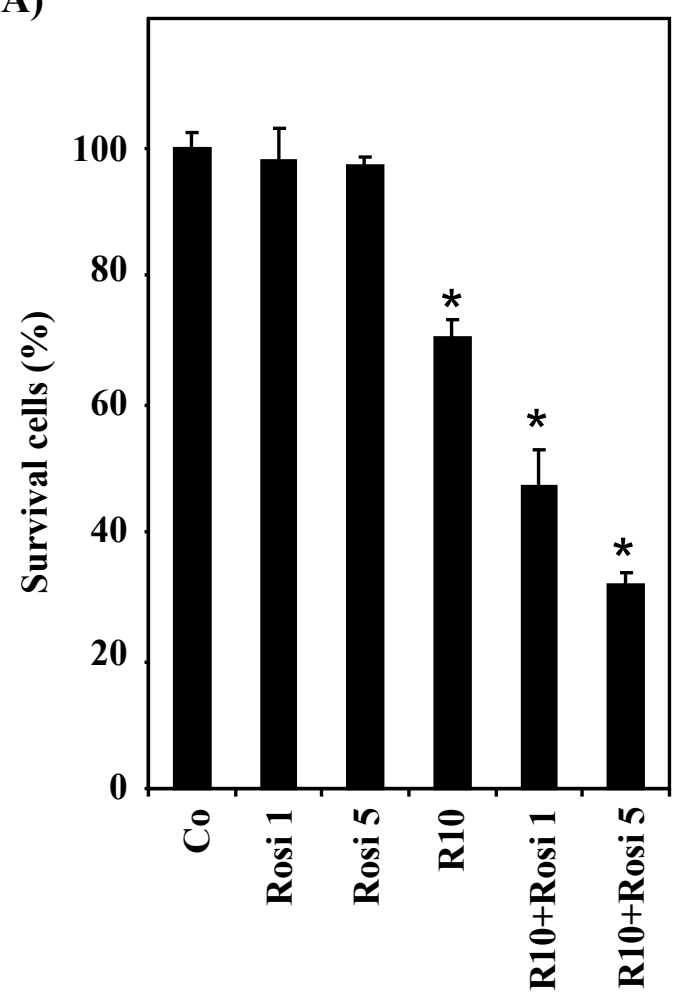

B)

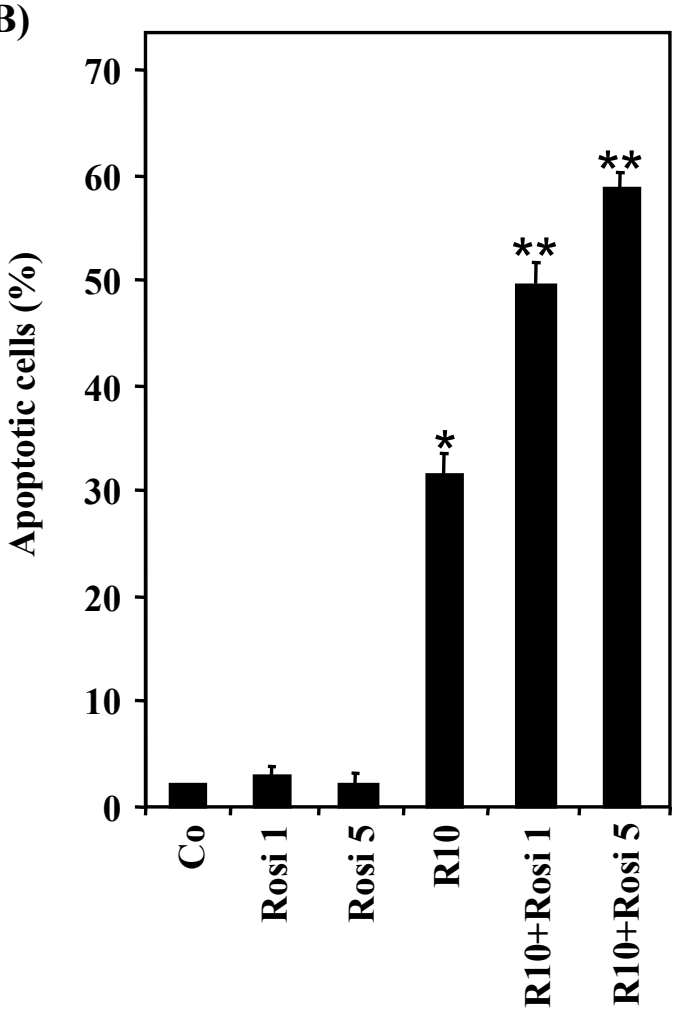

C)

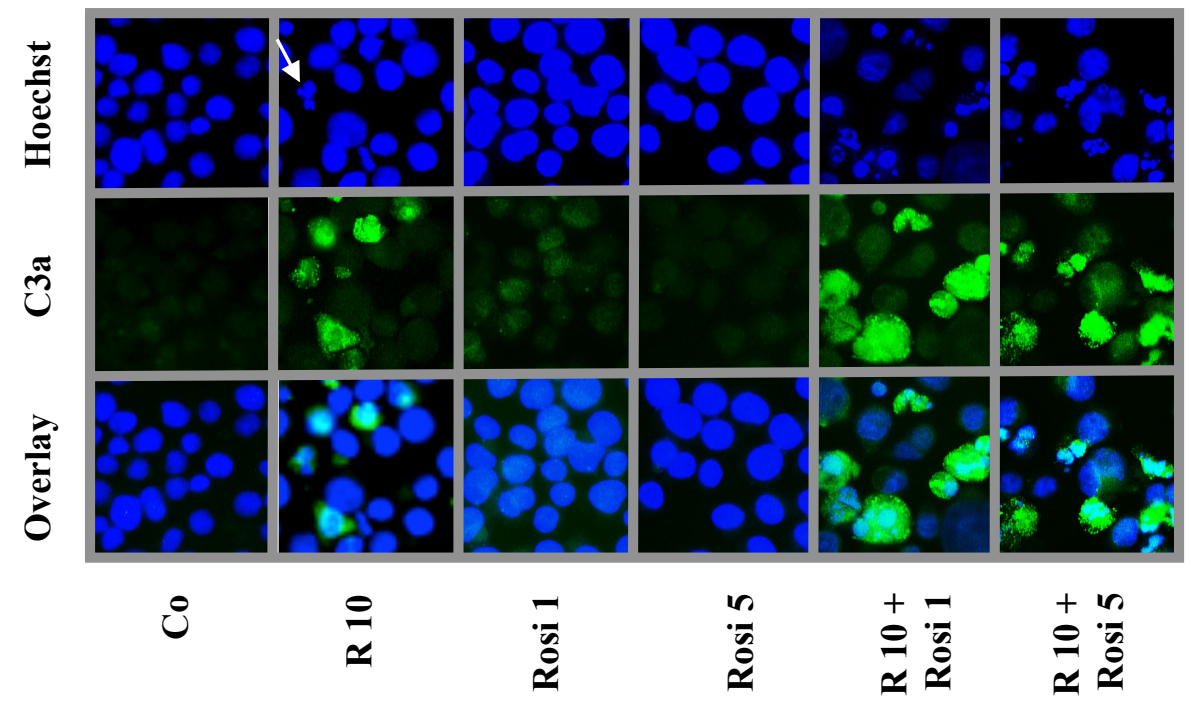




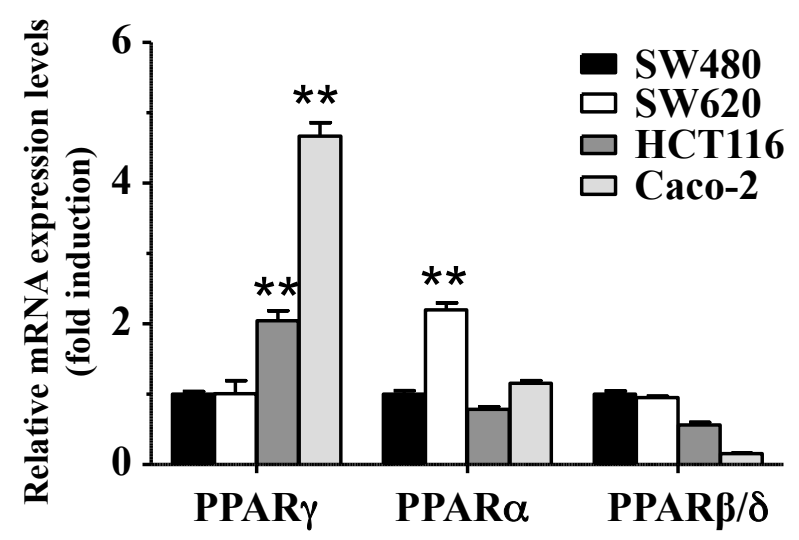

Figure S1. Relative mRNA expression levels of PPARs isoforms in human colon cancer cells. One microgram of RNA was reverse transcribed using the M-MLV Reverse transcriptase kit ADN RT-qPCR was perfromed using the Power SYBR ${ }^{\circledR}$ Green PCR. Amplification of specific transcripts were confirmed by melting curves obtained at the end of each PCR run. Standard curves were generated from pooled cDNA of assayed samples. All PCR efficiencies were between $95-105 \%$. The relative changes in gene expression were determined using the $\Delta \Delta \mathrm{CT}$ method. Fold change was calculated as $2^{-\Delta \Delta} \mathrm{CT}$. 

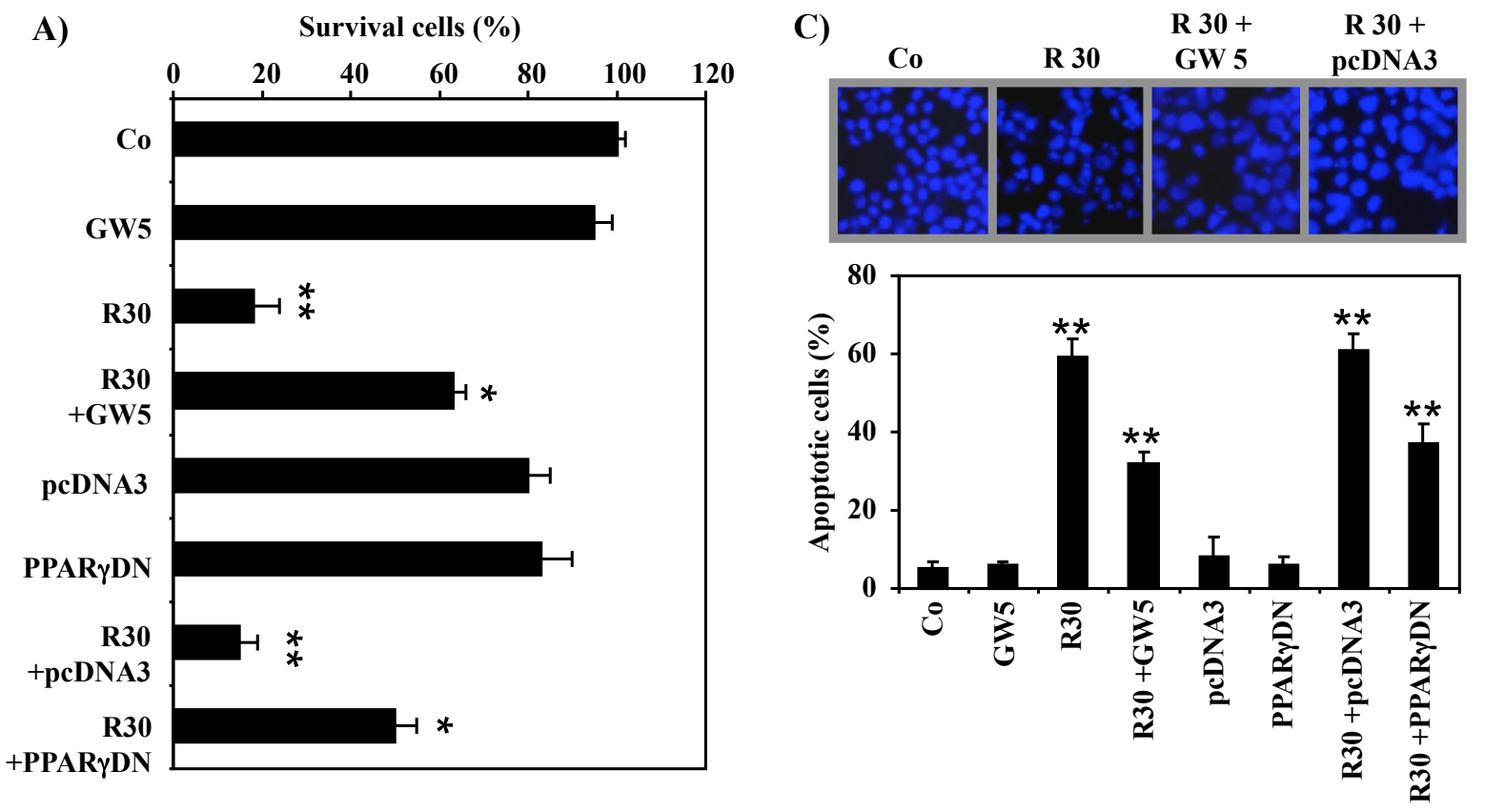

B)

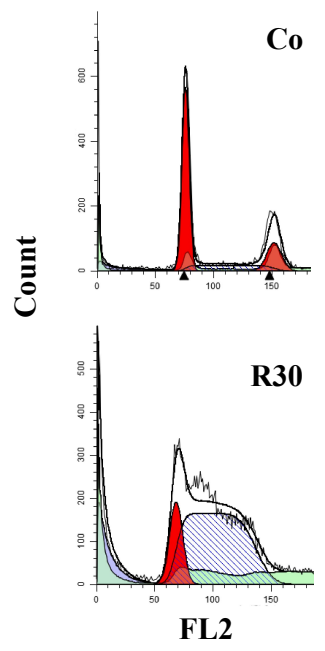

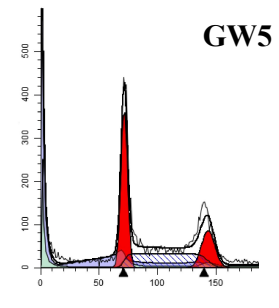

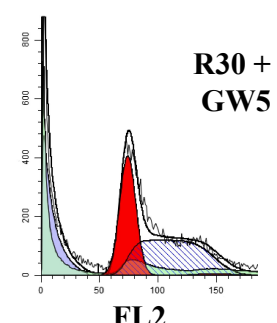

GW5

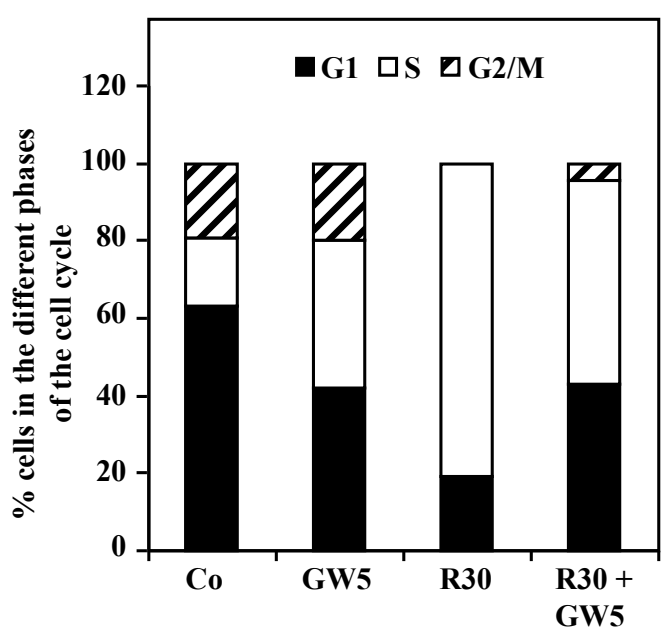

Figure S2. PPAR $\gamma$ dominant negative mutant and GW9662 antagonist of PPAR $\gamma$ inhibit resveratrolinduced biological effect in metastatic colon cancer cells SW620. (A) After $24 \mathrm{~h}$ of culture, SW620 cancer cells were left untreated (Co, $0.1 \%$ ethanol) or treated with RSV at $30 \mu \mathrm{M}$ (R30) with or without GW9662 at $5 \mu \mathrm{M}$ (GW5) for 48h or SW620 cells were transiently transfected with either an empty plasmid (pcDNA3) or a plasmid encoding a double dominant-negative mutant of PPAR $\gamma(\operatorname{PPAR} \gamma / \mathrm{DN})$. Twenty-four hours later, cells were treated with either $30 \mu \mathrm{M}$ of RSV (R30) or with the vehicle $(\mathrm{Co}, 0.1 \%$ ethanol) during $48 \mathrm{~h}$ before measuring cell survival using trypan blue exclusion. (B) After $24 \mathrm{~h}$ of culture, colon cancer SW620 cells were left untreated or treated for $48 \mathrm{~h}$ with RSV at $30 \mu \mathrm{M}$ (R30) with or without $5 \mu \mathrm{M}$ of GW9662, then staining with PI and analyzed by flow cytometry. One representative of three experiments is shown. Quantitative analysis of colon cancer SW620 cells distribution in the phases of the cell cycle (mean \pm S.D. of three independent experiments). (C) Treatments or transfections are realized as in A) and apoptosis was determined by nuclear staining with Hoechst 33342 . Original magnification $x 40$. The results are expressed in the percentage of apoptotic cells (mean \pm SE of three independent experiments in which each percentage was calculated by counting 300 cells). For panels A and C: mean \pm S.D. $(n=6)$ of three independent experiments; *, $\mathrm{p}<0.05$ and ${ }^{* *}, \mathrm{p}<0.001$. 
Supporting Information Figure S3 Aires et al.,

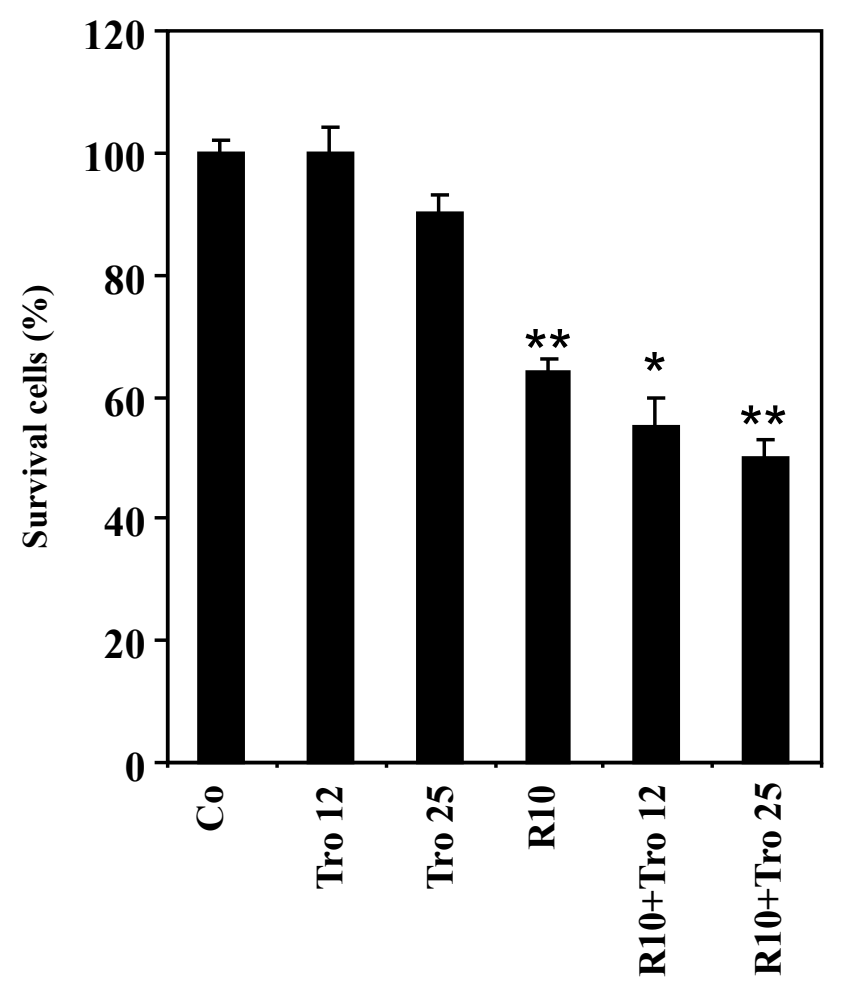

Figure S3. Figure 4. RSV combination with Troglitazone, a PPAR $\gamma$ agonist, increases colon cancer cell death. (A). SW480 cells were left untreated (Co) or treated for $24 \mathrm{~h}$ with $10 \mu \mathrm{M}$ of RSV, then exposed for $24 \mathrm{~h}$ to the PPAR $\gamma$ agonist Troglitazone $(12$ or $25 \mu \mathrm{M})$ before counting the percentage of viable cells after crystal violet staining $\left(n=6\right.$, three independent experiments). ${ }^{*}, p<0.05$. 